\title{
埋伏歯とインプラントを用いたオーバーデンチャー症例
}

\author{
神田省吾, 西野恒理, 小林裕之, 益川正道, 山上哲贒
}

\section{A Case of Overlay Denture Applied to Impacted Tooth and Implants}

Shogo Kanda, Watari Nishino, Yushi Kobayashi,

Masamichi Masukawa, Akiyoshi Yamagami

The POI Implant ${ }^{\circledR}$ (Japan Medical Material, JAPAN, OSAKA) series have broadly been clinically applied from the case of single tooth missing to the case of edentulous jaw, successfully rasing good clinical results. This author et al. have reported the case of overlay denture using the impacted tooth and Implant.

Conclusion

1) It is effective to use the FINATITE ${ }^{\circledast}$ for the purpose of abbreviation of the healing period for recovery of the FINAFIX ${ }^{\circledast}$.

2) It was effective to apply the TESLOX SYSTEM ${ }^{\circledast}$ in case any local conditions were infavorable or in case the parallelism between the abutments was wrong.

3) In case of combined use of tooth and implant, inserting of the implant is usually made in matched with the tooth.

In case, it is necessary to adjust the degree of parallelism between tooth and implant again upon setting the attachment, it is effective to apply the TESLOX SYSTEM ${ }^{\circledast}$.

POIインプラント@(日本メディカルマテリアル) シリーズは, 単独植立から無歯顎症 例まで幅広く臨床応用され，良好な臨床成績を収めている。

今回, 著者らは埋伏歯とインプラントを用いたオーバーデンチャー症例について報告する。 結果,

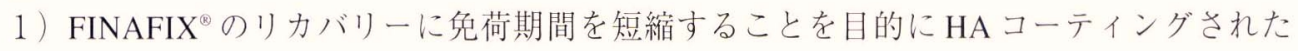

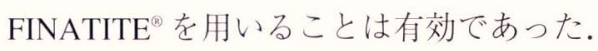

2 ）埋入部位の骨質，骨量などの局所条件や，支台間の平行性に問題がある場合は

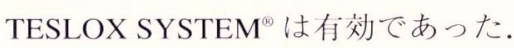

3 ) 天然歯とインプラントとの併用においては, インプラントの埋入時に天然歯の歯軸に あわせて埋人するが，アタッチメント装着時に再び天然歯との平行性を調整する必要 性がある。

Key words : オーバーデンチャー Overlay Denture, ボールアタッチメント BallAttachment, マグネットアタッチメント Magnet Attachment 


\section{Shift of Prostheses with age}
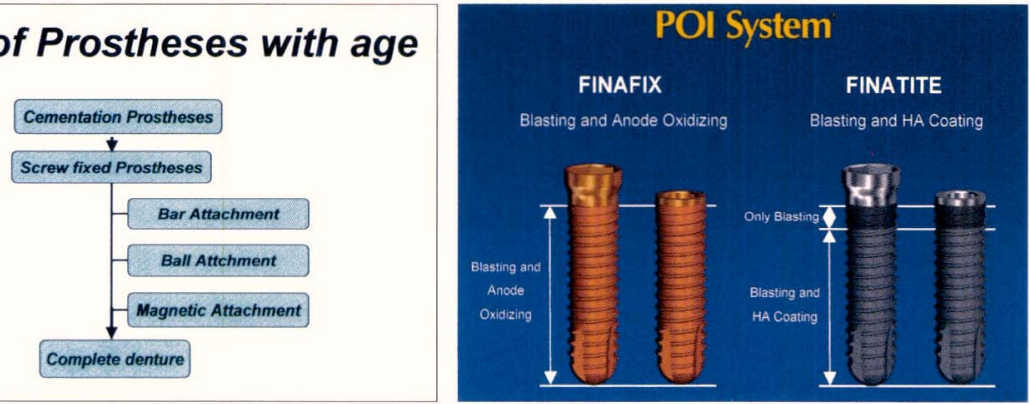

図 1 Shift of prosthese with age (Kanda, S. et. al. manuscript). 図2 POI Implant ${ }^{\circledR}$ system.
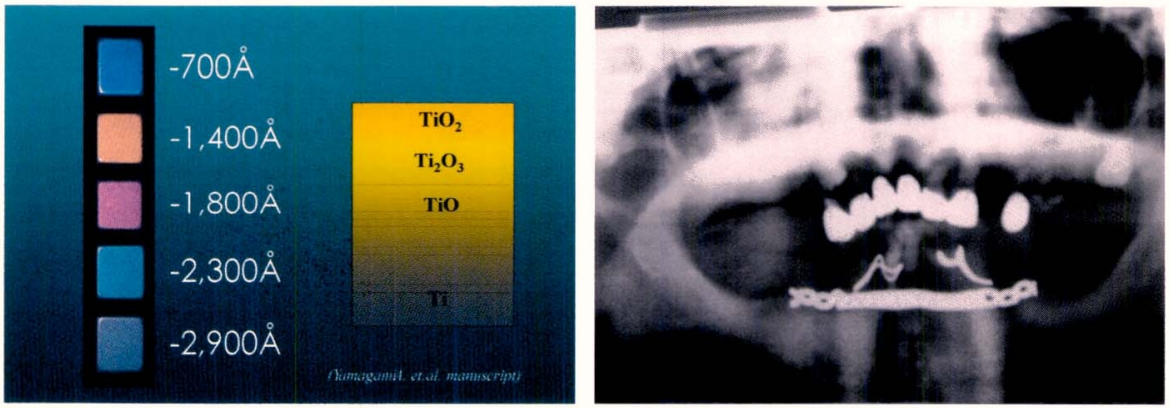

図3 Thickness of Anode Oxide Layer \& Color (Yamagami, A. et. al. manuscript) FINAFIX has an anodized layer of 1,350$1,400 \AA$ thick, which provides intimate compatibility with surrounding tissues, also giving protection from titaniumion release, and improved hydrophilicity and esthetic.

図 4 Preoperative panoramatic radiograph.

\section{緒言}

すでに多様なインプラント支台のオーバデンチャーにつ いて報告されている1，2,3,4,5). オーバデンチャーは固定式 補綴物に比べコストが安価であるとされている。しかし， 初期コストは安価であるが，ランニングコストまで考慮す るなら決して安価ではない。また，固定式補綴物に比べ， オーバデンチャーは長期的臨床成績は良くないと報告され ているが，これは適切なメインテナンスがなされていない ためと思われる6).

従来より著者らは，患者の高齢化，あるいは患者の全身 状態の変化に伴い, 補綴物の設計を見直す必要があると報 告してきた1,2,3) (図 1). 今回，われわれは埋伏歯とイン プラント支台にボールアタッチメントを用いた症例のリカ バリーにマグネットアタッチメントを用いた症例について 報告する．

1. インプラントシステム

今回用いたのは，骨結合型インプラントである POI イン プラントシステム®(日本メディカルマテリアル $)$ である (図 2).POI インプラント®は Ti-6Al-4V 合金製であり， 表面を陽極酸化処理された FINAFIX (図3）と，HA コー ティングされた FINATITE ${ }^{\circledR}$ か構成されており，1回法か ら 2 回法まで多様な臨床二ーズに応じられるインプラント
システムであることは，すでに報告している7, 8,9) (図2).

\section{2. 症例}

患者：54 歳男性.

主訴：上下顎インプラント補経希望.

既往, 家族歴：特記事項なし.

現病歴：上下㖽とも部分床義歯が装着されていたが, 残存 歯の動摇掞よび義歯不適合のため，1996年 11 月 14 日イン プラント補綴希望にて来院.

現症：パノラマX線写真により, 残存歯は 52$\rfloor,\lfloor 235,21$ であり，迆の残根，および4 ， 8 の埋伏が認められた（図 4).

処置：6の残存歯は，骨吸収が著しく，動摇していたた め，迆残根とともにすべて抜歯した（図５）. また，4 埋 伏歯の開空術を施術した。柬槽粘膜治癒後, 下顎に総義歯 を装着した。総義歯の良好な維持安定が得られたため，下 顎にはインプラント埋入は行わなかった.

上顎については, Top down treatment のコンセプトから， 3 本のインプラント埋入を予定し, 開空した 4 とを用いて, 4 本支台を考慮していたが，経済的理由から，一度の3 本 の埋入には同意が得られなかった。

そのため, 最初に口腔内の操作性, および術後の清掃性 を考虑し， 44 に 2003 年 6 月 24 日にPOI 3 ピースインプラ ント，FINAFIX ${ }^{\circledR 7}$-10TN（幅径 $3.7 \mathrm{~mm}$ ，骨内長 $10 \mathrm{~mm}$ ）を 


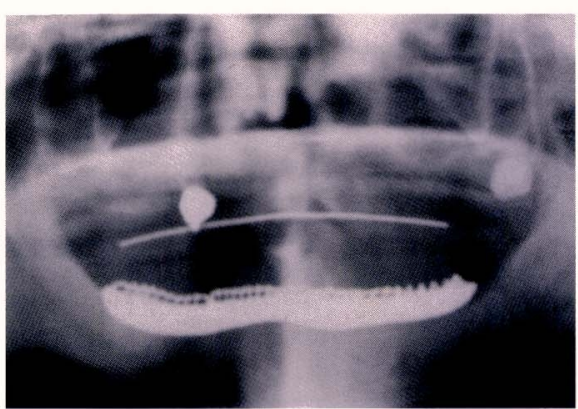

図 5 panoramatic radiograph after extraction.

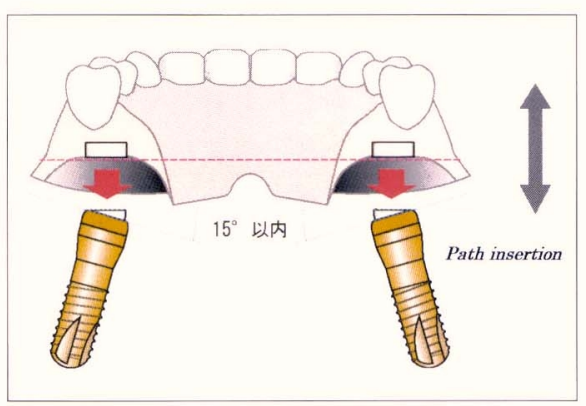

図 8 Path insertion(TESLOX SYSTEM").

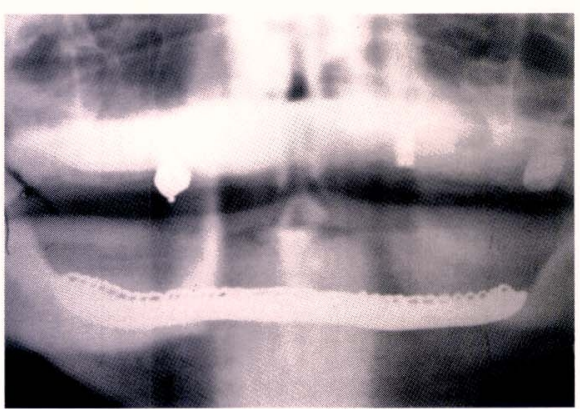

図 6 panoramatic radiograph after 図 7 TESLOX SYSTEM ${ }^{\infty}$ insertion at 24

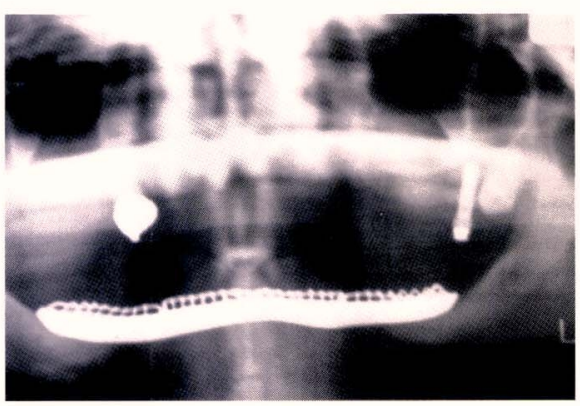

図 9 panoramatic radiograph after the placement prosthese.
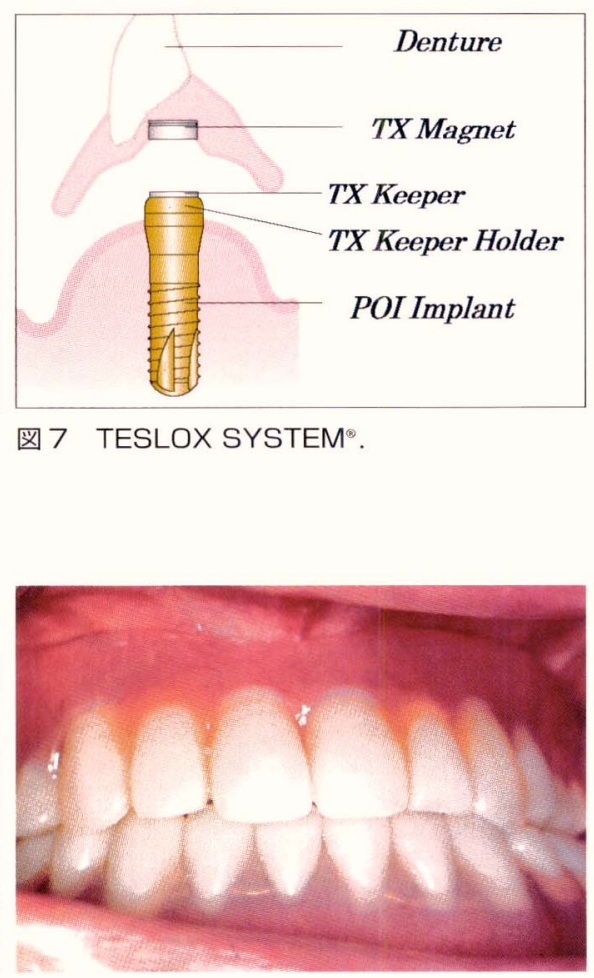

図 10 Intraoral view after the placement prosthese.

\section{埋入した（図 6).}

術後経過良好にて, 2003 年 12 月 3 日にアバットメント を装着した。粘膜治癒後，4 とアバットメントにアタッチ メントメールを装着し, ボールアタッチメントを使用した オーバーデンチャーを新調した. 満足のいく維持, 安定を 得られたものの, 義歯着脱の困難なことを指摘された。 また,アタッチメントメールの数回の緩みにて来院された

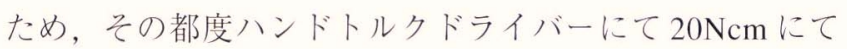
締め直した。

2004 年 1 月 19 日, インプラントの動摇のため来院，た だちにインプラントを除去した。

2 月 19 日, 免荷期間短縮を目的に，フイクスチャー表面 をHA コーティングされたFINATITE ${ }^{\circledast}$ (幅径 $3.7 \mathrm{~mm}$, 骨内 長 $12 \mathrm{~mm}$ ）を原に埋入した.

3 力月の免荷期間後, アバットメントを装着後, マグ

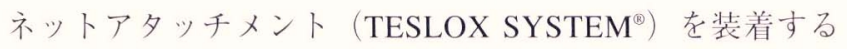
ことにした(図7,8).

\section{(以後 TESLOX SYSTEM ${ }^{\otimes}$ )}

アバットメントにキーパーホルダーを装着後，4」の歯軸 にあわせキーパーをレジンセメントにてキーパーホルダー に合着した。その後, マグネットをデンチャーの装着した。 このため, 本症例は 4 のボールアタッチメントと７部の
インプラントの TESLOX SYSTEM ${ }^{\circledast}$ を併用した複合支持様 式の補緅物となった（図9，10）。

義歯の維持, 安定そして着脱も改善されたが，2005 年 2 月 3 日 5 に EINAFIX ${ }^{\circledR} 37-10 \mathrm{NT}$ (幅径 $3.7 \mathrm{~mm}$, 骨内長 $10 \mathrm{~mm}$ ）在追加埋入した（図１１）.

6月1日，5ににアバットメント装着し, 粘膜の治癒した

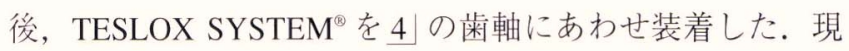
在経過良好であるが，随時追加埋入を予定している。

\section{考察}

予後不良症例は, early failure と late failure とに分類でき る(図 12). early failureは, osseointegrationの獲得の失敗 を, late failureは osseointegrationの琵失を意味する。

本症例においては, 口腔内操作性, 清掃性などのメイン テナンスの容易性などから， 4 に埋入したが, 補綴物装着 後のフィクスチャーの㳖失を生じたため, late failure に属 する。しかし補綴物装着直後の丧失であり, その原因とし $\tau$,

1）除去されたフィクスチャー窩の触診により，煩側の骨 の欠損が認められたため, 骨量, 骨質など局所条件の 不良な部位に埋入されたことが考えられる。

2) 4 とアタッチメントメールとの並行性が得られていな 

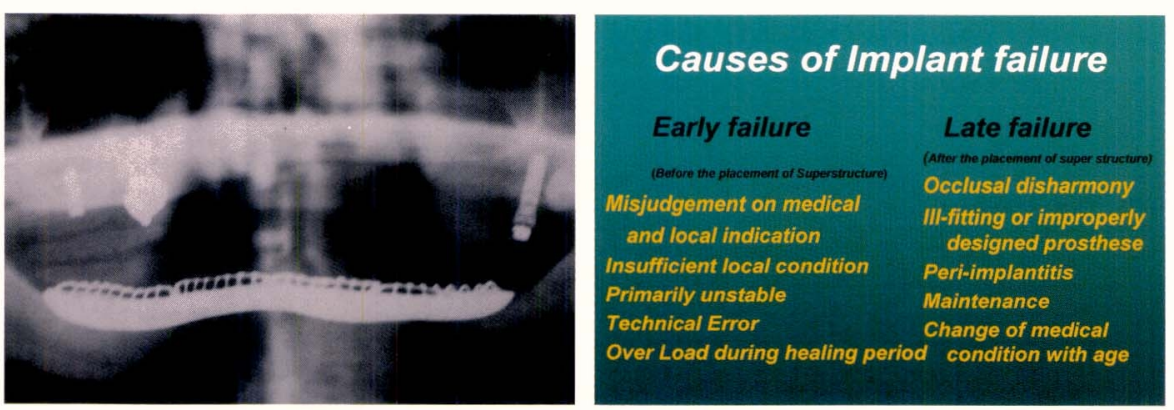

図 11 panoramatic radiograph after insertion at 15 .
S. et. al. manuscript)

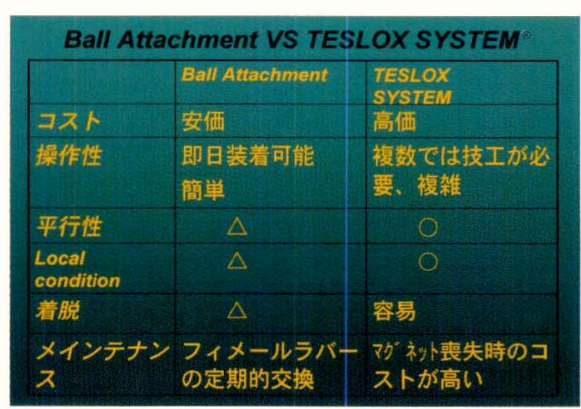

Comparison between Ball Attachment and TESLOX SYSTEM ${ }^{*}$ (Kanda, S. et. al. manuscript)
かったため，義歯の着脱時に過剩な負荷を与えること になったと考えられる。

これらのことから，本症例はlate failureに属するが， early failure の要因が大きい. また, 暫間的とは言え, 天然

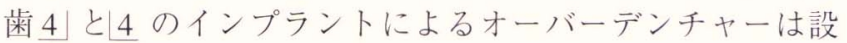
計上無理があった。

維持，把持，支持，すべてを得るには，4 点支台が必要 である．３点支台では，支持と維持あるいは把持のみとな る。今段階では 2 点支台であるため，支持あるいは維持の みしか得られていないため, 追加埋入が必要となる ${ }^{6}$.

従来より，固定式補綴物に比べ，オーバーデンチャーの survival rate が低いと報告されている。これは清掃性など メインテナンスに問題があるためと思われる

この症例においては，義歯の調整のみならず，インプラ ント周囲の炎症のコントロール，天然歯のカリエス，歯周 組織に対するメインテナンス，あるいはフィラメントラ バーの交換，またボールアタッチメントからマグネットア タッチメントへの変更, およびインプラントの追加埋入が 考えられる。以上のことから，インプラントは，メインテ ナンスの容易な部位に埋入することが必要であり，また使 用するアタッチメントはメインテナンスの容易なシンプル な構造のものを選択する必要がある。

アタッチメントの選択については，以下のような基準で 選択される。

\section{1) クリアランス}

2) 維持力

3）顎堤の条件

4) 義歯の安定性

5）メインテナンスの難易度など ${ }^{6}$

$\mathrm{POI}^{\circledR}$ システムにおいては, ボールアタッチメントと TESLOX SYSTEM ${ }^{\circledast}$ 選択できる。ボールアタッチメント はシンプルな構造であり，初期コストが安価である。
しかも, 即日装着可能というメリットを有している。し かしフィラメントラバーの定期的交換が必要なことと, 本 症例のように，支台間の平行性に問題のあるケースには使 用が困難である。

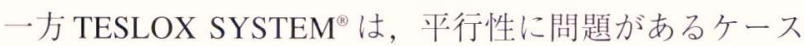
において，15の範囲で調整が可能であること，あるいは 骨幅，骨質など局所条件に問題があるなど， stress breakが 必要な症例に有効であるが，複数の支台がある場合などて は，技工操作が必要となり，即日装着は困難となり，ある いはマグネット垜失時のコストが高価であるなどのデメ リットがあげられる(図 13)。以上のそれぞれのアタッ チメントの特性を考慮し，今回はTESLOX SYSTEM を選 択することにした。

4|の歯軸にあわせて 17 に埋入し, マグネット装着時に再 度 4 と平行になるように装着した。 以上のことから本症 例は，埋伏歯，歯槽粘膜の複合支持となり，インプラント は維持にのみ作用することとなった。その後の5」の部の TESLOX SYSTEM ${ }^{\circledast}$ の追加により, 維持力は著しく増加し, 経過良好である。

\section{結果}

1）FINAFIX のリカバリーに免荷期間を短縮することを目 的にHA コーティングされたFINATITE ${ }^{\oplus} を$ 用いること は有効であった。

2）埋入部位の骨質，骨量などの局所条件や，支台間の平 行性に問題がある場合はTESLOX SYSTEM は有効で あった。

3）天然歯とインプラントとの併用においては, インプラ ントの埋入時に天然歯の歯軸にあわせて埋入するが, アタッチメント装着時に再び天然㐘との平行性を調整 する必要性がある。 


\section{参考文献}

1）神田省吾, 桑原明彦, 山上哲贒 : 高齢者の骨結合型インプ ラントの長期経過報告. 顎咬合誌，24（2・3）：367-361, 2004.

2）神田省吾, 竹内宏行, 山上哲贒 : 予後不良症例の臨床的検 討. 顎咬合誌，25（1－2）：144-147， 2005.

3）神田省吾, 竹内宏行, 三田村聡, 山上哲賾 : 予後不良症例 のリカバリー。顎咬合誌，25（3）：422-425， 2005.

4) 柏原毅, 浅賀寞, 根深研一, 若井広明, 深井真樹, 井上達, 井汲憲治, 大田義秋：義歯の維持装置としてプラトンマグ ネットヘッドシステムを応用した 1 症例. 日ロ腔インプラ ント誌, $12 ： 577-582,1999$.

5）五十嵐俊男, 中島三晴, 杉藤庄平, 奥森直人, 北村隆, 鬼 沢徹, 山倉和典, 梁瀬武史, 今西泰彦, 羽倉隆昌, 高木亮, 村上広樹：インプラント支台のオーバーデンチャーの 2 症 例，Oリングならびに磁性アタッチメントを用いた臨床例. 日ロ腔インプラント誌, $12 ： 64-71,1999$.
6）前田芳信：臨床に生かすオーバーデンチャー, 一インプラ ント，天然歯支台のすべて一. 68,73,76,84,88, クインテッ センス出版 (東京), 2003.

7）松浦周, 尾崎健太郎, 長谷川暢久, 深沢貴子, 脇山智子, 小林裕之, 山上哲賢 : 骨結合型インプラント臨床 8 年の検 討. 日ロ腔インプラント誌, $15 ： 467-472,2002$.

8）峯崎恵：POI 2 ピースインプラント処置 7 年後の症例に関す る考察. 日口腔インプラント誌, $12 ： 400-407,1999$.

9) Akiyoshi Yamagami,Yusuke Yoshihara, Fumihiko Suwa : Mechanical and Histologic Examination of Titanium Alloy Material Treated by Sandblasting and Anodic Oxidization. The international journal of Oral \&Maxillofacial Implants, 20 (1) , 4853, 2005. 